' Hadwiger, L. A., Badiei, S. E., Waller, G. R., and Gholson, R. K., Biochem. Biophys. Res. Commun., 13, 468 (1963).

${ }^{10}$ Henderson, L. M., Gholson, R. K., and Dalgliesh, C. E., in Comparative Biochemistry (edit. by Florkin, M., and Mason, H. S.), 4, 241 (Academic Press, New York, 1962).

"Yang, K. S., and Waller, G. R., Phytochemistry, 4 (1965).

${ }^{12}$ Ortega, M. V., and Brown, G. M., J. Biol. Chem., 285, 2939 (1960).

${ }^{13}$ Gross, D., Schütte, H. R., Hübner, G., and Mothes, K., Tetrahedron Lett. No. $9,541(1963)$

${ }^{14}$ Nakamura, S., Ikeda, M., Tsuji, H., Nishizuka, Y. and Hayaishi, O., Biochem. Biophys. Res. Commun., 13, 285 (1963).

${ }^{15}$ Gholson, R. K., and Kori, J., J. Biol. Chem., 239, PC 2399 (1964).

18 Packman, P. M., and Jakoby, W. B., Biochem. Biophys. Res. Commun., 18 710 (1965).

${ }^{17}$ Halpern, Y. S., and Grossowicz, N., Biochem. J., 65, 716 (1957).

${ }^{18}$ Joshi, J., and Handler, P., J. Biol. Chem., 235, 2981 (1960).

${ }^{19}$ Petrack, B., Greengard, P., Craston, A., and Kalinsky, H. J., Biochem. Biophys. Res. Commun., 13, 472 (1963).

${ }^{20}$ Imsande, J., and Handler, P., J. Biol. Chem., 236, 525 (1961).

${ }^{21}$ Imsande, J., Biochim. Biophys. Acta, 82, 445 (1964).

${ }^{22}$ Cantoni, G. L., J. Biol. Chem., 189, 203 (1951).

${ }^{23}$ Wagner, C., Biochem. Biophys. Res. Commun., 17, 668 (1964).

${ }^{24}$ Heidelberger, C., Abraham, E. P., and Lepkovsky, S., J. Biol. Cheni., 179, 151 (1949).

${ }^{25}$ Narrod, S. A., Bonavita, V., Ehrenfeld, E. R., and Kaplan, N. O., J. Biol. Chem., 236, 931 (1961).

${ }^{26}$ Roth, L. J., Leifer, H., Hogness, J. R., and Langham, W. H., J. Biol. Chem. $176,249(1948)$

${ }^{27}$ Greengard, P., Quinn, G. P., and Reid, M. B., J. Biol. Chem., 239, 1887 (1964).

${ }^{28}$ Greengard, P., Petrack, B., Canston, A., and Kailinsky, H. J., Biochem. Biophys. Res. Commun., 13, 478 (1963).

${ }^{29}$ Grunicke, H., Liersch, M., Hinz, M., Puschendorf, B., Richter, E., and Holzer, H., Biochim. Biophys. Acta, 121, 228 (1966).

${ }^{30}$ Dietrich, L. S., Fuller, L., Yero, I. L., and Martinez, L., J. Biol. Chem., 241, 188 (1966).

${ }^{31}$ Takei, S., Totsu, J., and Nakanishi, K., Agric. Biol. Chem., 30, 169 (1966).

\section{Two Different Forms of Glutamic Pyruvic Transaminase in Rat Heart and their Intracellular Localization}

Several workers ${ }^{1-4}$ have shown that there are two electrophoretically and chromatographically separable forms of GOT*. These two forms are found at different sites in the cell and have different properties, and it has been shown that they are both isoenzymes of GOT. While one isoenzyme is localized in mitochondria the other is localized in the cytoplasm, and moreover, unlike the latter, the mitochondrial enzyme is markedly inhibited by its reaction product $\mathrm{OAA}$.

The purpose of this report is to emphasize the similarities in localization and biochemical properties between GOT and GPT. An attempt was made to separate GPT isoenzymes both in water-soluble rat heart extract and in rat heart mitochondria by gradient elution chromatography with DEAE-cellulose columns and an ascending sodium chloride gradient of up to $0.8 \mathrm{moles} / \mathrm{l}$. in 0.05 molar tris-hydrochloric acid buffer $(p H 8)$. The activity of GPT in each fraction collected was determined using the method of Karmen ${ }^{5}$ as well as that of Reitman and Frankel $^{6}$. The results are shown in Fig. 1. Different forms of GPT were found in both cell fractions investigated; the first passed through the column without adsorption. while the other was adsorbed by DEAE-cellulose and appeared in the eluate after treatment with sodium chloride. The enzyme which could not be adsorbed is mainly found in mitochondria whereas the other only appeared in the chromatogram of the cytoplasmic extract. Thus the chromatographic behaviour of these two GPT isoenzymes is related to their intracellular localization in a way which corresponds with that of the GOT isoenzymes.

I was able to detect the activity of the mitochondrial GPT only by the method of Karmen. This could possibly be explained by assuming that the mitochondrial GPT isoenzyme is strongly inhibited by its reaction product-pyruvic acid-which accumulates in the Reitman and

* Abbreviations used: GPT, glutamic pyruvic transaminase; GOT glutamic oxalacetic transaminase; OAA, oxalacetic acjd.

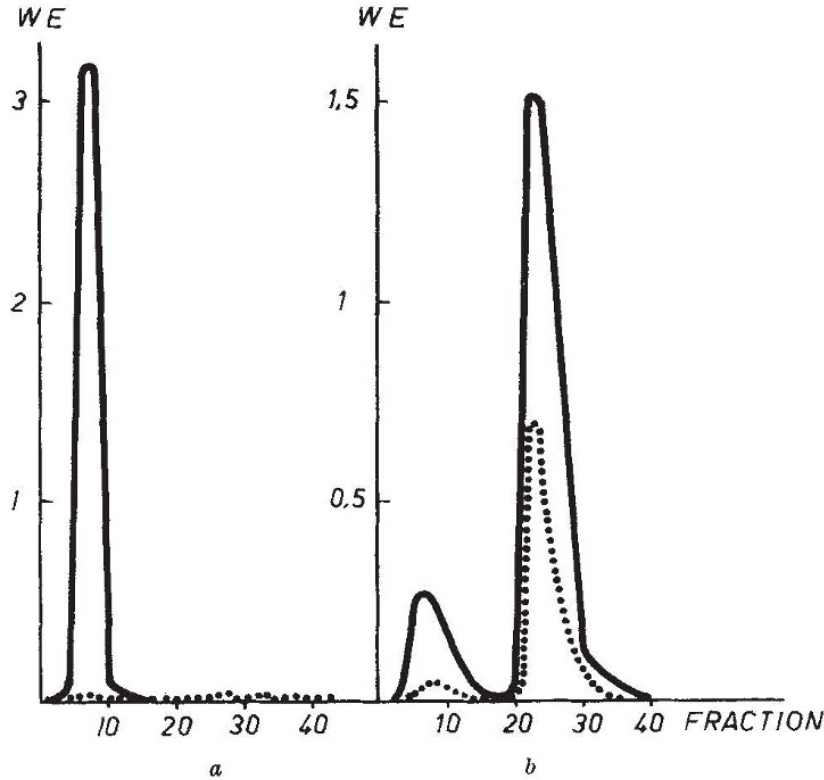

Fig. 1. $a$, Activities of GPT from isolated rat heart mitochondria after chromatographic separation on a DEAE-cellulose column. The enzyme activities are expressed in Wroblewski units $/ \mathrm{ml}$. eluate. $b$, Activities of GPT in water soluble rat heart extract after chromatography on a DEAEcellulose column. ㄴ._. Method of Karmen;...., method of Reitman and Frankel.

Frankel reaction mixture. This behaviour represents another similarity between GPT and GOT. The investigations are being continued.

Renate Ziegenbern

Deutsche Akademie der Wissenschaften

zu Berlin,

Institute für Medizin und Biologie,

Berlin-Buch.

${ }^{1}$ Boyd, J. W., Biochem. J., 81, 434 (1961).

"Reith, A., Möhr, J., Schmidt, E., Schmidt, F. W., and Wildhirt, E., Klin. Wschr., 42,909 (1964).

3 Eichel, H. J., and Bukowsky, J., Nature, 191, 243 (1961).

${ }^{+}$Borst, P., and Peeters, E. M., Biochim. Biophys. Acta, 54, 188 (1961).

' Karmen, A., J. Clin. Invest., 34, 131 (1955).

Reitman, S., and Frankel, S., Amer. J. Ctin. Path., 28, 56 (1957).

\section{Proteolytic Enzyme Control in Squash Cotyledons}

THE formation of $\alpha$-amylase in the endosperms of germinating barley seeds is controlled by endogenous gibberellic acid from the axial tissue ${ }^{1}$. Increases of soluble nitrogen in excised barley endosperms have resulted from the addition of gibberellic acid ${ }^{1-8}$. This communication shows that the proteolytic activity in seedlings, where the stored protein is in the cotyledons rather than in the endosperm, is influenced by growth regulators.

Cucurbita maxima var. 'Hubbard' was studied because its cotyledons are retained as functional leaves for a considerable period of time. The proteolytic activity in cotyledons (embryonic axial tissue removed before germination) was compared with that in cotyledons of the intact seeds. After the seed coats were removed, the axis was excised from half of the seeds. Ten intact seeds, or ten cotyledons, were placed in each of several Petri dishes containing $12 \mathrm{ml}$. of various solutions (Table 1) containing $20 \mu \mathrm{g} / \mathrm{ml}$. of streptomycin in order to inhibit microbial growth. The cultures were incubated for $48 \mathrm{~h}$ at $30^{\circ} \mathrm{C}$. The enzyme preparation was obtained by blending the cotyledons or the cotyledons from the intact seeds in 